\title{
SPORTMOTIVÁCIÓS TÉNYEZŐK VIZSGÁLATA A 8-18 ÉVES FOGYATÉKOSSÁGGAL ÉLŐ KOROSZTÁLY KÖRÉBEN
}

\author{
Laoues-Czimbalmos Nóra - Bácsné Bába Éva \\ Szerdahelyi Zoltán - Müller Anetta
}

\section{Összefoglalás}

A fogyatékossággal élö személyek sportmotivációs tényezök vizsgáló tanulmányok nem képeznek olyan teljességre törö rendszert, mint az épek sportolásával foglalkozó kutatások. Így a fogyatékossággal élö személyek életminöségét meghatározó testedzési szokások, sportmotivációs tényezök felmérése hazai és nemzetközi viszonylatban is egy hiányterületnek mondható. A kutatás a 8-18 éves korosztály sportmotivációs tényezöit vizsgálja és egy pilot kutatás eredményeiröl számol be. A hazai fogyatékossággal élo" lakosság körében végzett kérdöiv gyerek mintára történö adaptálását és annak eredményeit mutatjuk be. A fogyatékossággal élö gyerekek körében még nem végeztek hazánkban ilyen felmérést. A kérdöives kutatásban a fogyatékossággal élö fiatalok sportolási motivációjukat, a fogyatékosok számára nyújtott sportkinálatot és azzal való elégedettséget mértük. Az adatokat SPSS szoftver használatával elemeztük, számitottunk alapstatisztikát és összefüggés vizsgálatot (Chi2 próbával). A fogyatékossággal élö fuík sportolási igénye (90,7\%) szignifikánsan nagyobb a lányokétól (78\%). A sportolási motivációban az egészség, a külsö megjelenés, a szórakozás-kikapcsolódás dominál.

Kulcsszavak: fogyatékossággal élök, sportolási motiváció

JEL: Z2

DOI: 10.33032/acr.2019.9.1.121 
INVESTIGATING SPORTSMOTIVATION FACTORS AMONG THE AGES OF 8 TO 18 YEAR OLDS WITH DISABILITIES

\begin{abstract}
Studies on the motivational factors of persons with disabilities do not constitute an exhaustive system such as research on the sport of intestines. Thus, the assessment of physical habits and sports motivation factors determining the quality of life of persons with disabilities can be considered as a deficit area both in Hungary and internationally. The research examines the motivation factors of the 8-18 age group and reports on the results of a pilot research. The adaptation of the questionnaire to the Hungarian sample of children with disabilities and their results is presented. Such a survey has not yet been conducted in Hungary with children with disabilities. In the questionnaire survey, young people with disabilities measured their sports motivation, the supply of sport for the disabled and their satisfaction with it. The data was processed using SPSS software, in addition to basic statistics, Chi2 test was used to examine the correlations. Disabled boys' sporting needs (90.7\%) are significantly higher for girls (78\%). Sports motivation is dominated by health, appearance, and entertainment.
\end{abstract}

Keywords: disabled people, sports motivation

JEL: Z2 


\section{Bevezetés}

A megváltozott munkaképességű és fogyatékossággal élőkre fókuszáló kutatások napjainkban vettek lendületet (Balázs-Földi 2017, Hidvégi et. al. 2018, Mező-Mező 2018, Bocsi-Rákó 2015), éppen ezért nem képeznek olyan teljességre törő rendszert és nem olyannyira átfogóak, mint az épekkel foglalkozó szakirodalmak.

A WHO (2018) fizikai aktivitásra vonatkozó legújabb kiadványa már igen sok országban külön tartalmazza a fogyatékossággal élő személyek számára megfogalmazott fizikai aktivitásra vonatkozó ajánlást.

Fontosak azok a kutatások, melyek a sport és turisztikai szolgáltatások keresleti és kínálati oldalának feltérképezését nem csak az épek (Bácsné et. al. 2018) de a fogyatékossággal élő személyek (Tatár et. al. 2018) számára is tartalmazzák, biztosítva ezzel az információt a hozzáféréshez.

A fogyatékossággal élő személyek sportolását vizsgáló hazai (Sáringerné 2014, Laczkó- Rétsági 2015, Tóthné- Gombás 2016) és nemzetközi (Block et al. 2013, Shapiro- Martin 2016, Bota et al. 2014,) kutatások is ismertek, bár számuk sokkal csekélyebb, mint az épekre fókuszáló ilyen jellegű szakirodalmak.

A Magyar Ifúság Kutatás (2016) vizsgálta a testmozgás motivációit (SzékelySzabó 2017). Olyan tényezőket azonosítottak, mint az edzettség és az egészség elérése valamint fenntartása, az örömforrás, a jó közérzet elérése és a jó fizikai megjelenés. Emellett a fogyás, a társasági esemény, illetve a szülői javaslat is ösztönzőleg hat a fiatalokra. Egy korábbi sportmotivációs vizsgálatban azt tapasztalták, hogy míg a fiatal férfiakat leginkább a fizikai fittséggel és az edzettséggel, a teljesítményfokozással kapcsolatos tényezők, illetve a közösségben eltöltött szabadidő, azaz a társaság motiválta szignifikánsan nagyobb mértékben, mint a nőket. A hölgyek válaszaiban pedig a sportmotivációban inkább dominál az esztétikus külső megjelenés elérése a sport mozgásanyagával, illetve a testsúly megtartásának biztosítása. (Székely 2013).

\section{Anyag és módszer}

Erre a kutatásra az Észak-alföldi régió három megyéjében (Jász-Nagykun-Szolnok, Hajdú-Bihar, és Szabolcs-Szatmár-Bereg) lévő gyógypedagógiai és integrált nevelésben-oktatásban résztvevő tanulóinak körében végeztük. A kitöltők általánosés középfokú oktatási intézményben tanulnak. A kutatásban online kérdöívezést alkalmaztunk. A kérdőíveket 283 fő diák töltötte ki. A tanulók az adatfelvétel során kérdezőbiztosok (pedagógusok) segítségével, irányításával végezték a kérdőívek kitöltését. A kérdőívek kitöltése név nélkül történt, az adatgyűjtésben való részvétel önkéntes volt. Az adatok feldolgozása után SPSS statisztikai programmal elemeztük a 
kapott eredményeket az alapstatisztikán túl az összefüggések vizsgálatára Chi2 próbát alkalmaztunk.

A vizsgálat során célunk volt megvizsgálni a fogyatékos gyerekek sport iránti attitüdjét, a sport motivációs hátterét. További célunk, hogy sportolás és a sporttól való távolmaradás okait feltérképezzük a 8-18 éves fogyatékosok között. A kutatásunkban az alábbiakra kerestük a választ:

- Hogyan alakul a vizsgált mintában a sport iránti igény?

- Mi motiválja a fogyatékossággal élő gyerekeket a sportolásra?

- Mik a sporttól való távolmaradás legfóbb okai?

\section{Eredmények}

\section{Demográfiai jellemzök:}

A kitöltők általános- és középfokú oktatási intézményben tanulnak, 283 fó tanuló vett részt, 53,5\%-a fiú ( $\mathrm{n}=151)$, 46,5\%-a lány ( $\mathrm{n}=132)$ volt. A válaszadók között legnagyobb arányban 50,9\%-uk tanulásban akadályozott, valamint 26,7\%-uk értelmileg akadályozott, továbbá 9\%-uk mozgáskorlátozott. A többi fogyatékossági ágban tartozó tanuló közel azonos arányban vettek részt a kutatásban. Az egyéb pszichés fejlődési zavarral küzdők tanulók 4,1\%, a látássérültek 3,7\%, a hallássérültek aránya 3,4\% és 2,2\% a beszédfogyatékos tanulók arány. A válaszadók fogyatékosspecifikus megoszlását az 1. sz. ábra szemlélteti.

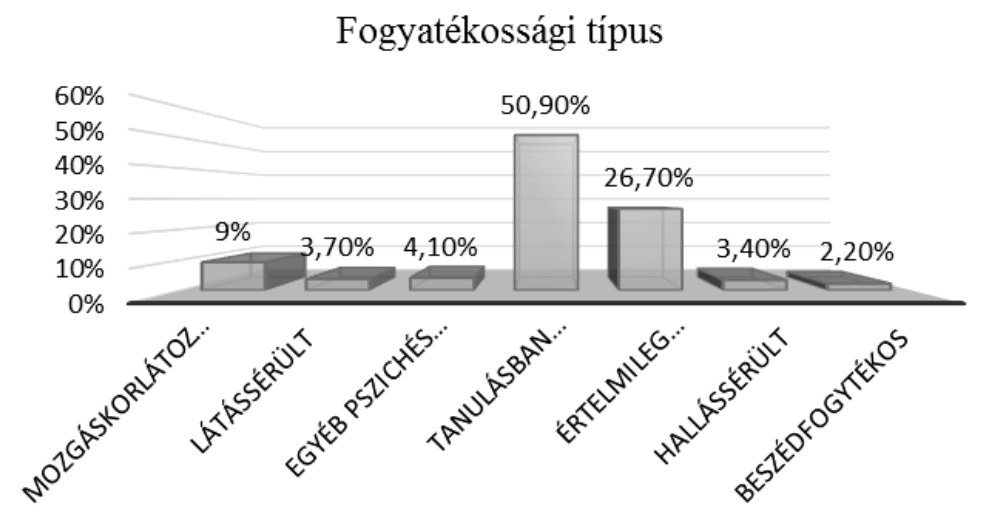

1. ábra: A válaszadók fogyatékossági típus megoszlása

Forrás: a szerzök, 2018 
Ebben a kutatásban a feltett kérdésekre a felső tagozatos tanulók 54\%-a ( $\mathrm{n}=153)$ adta a legtöbb választ, 39,2\%-a $(\mathrm{n}=111)$ a középiskolás diákokból került ki és az alsós osztályokban járók a legkevesebben 6,8\%-ban $(\mathrm{n}=19)$ válaszoltak. A mérésben résztvevő általános- és középiskolások elemszámát és százalékos arányát összegzi a 2. ábra.

A felmért tanulók iskolatípus szerint megoszlása

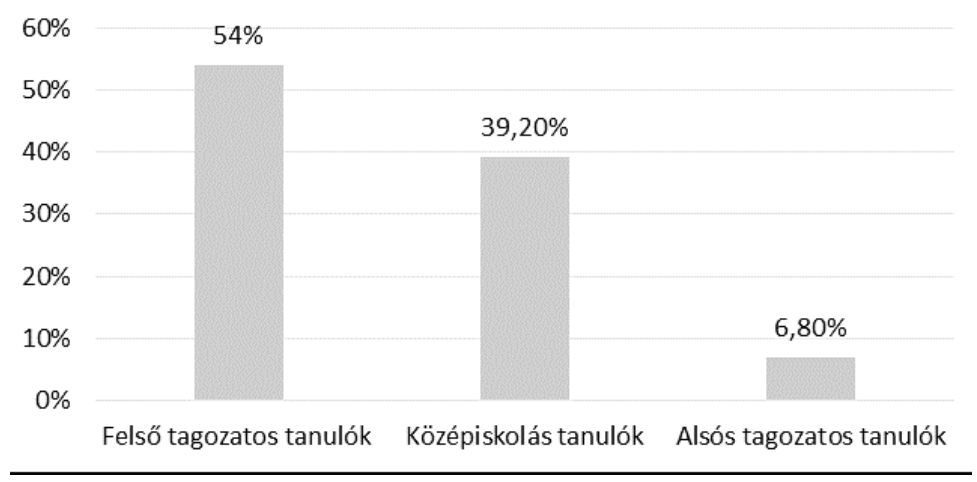

2. ábra: A válaszadók iskolatípus szerinti megoszlása

Forrás: a szerzők, 2018

A feleletadók lakóhely szerinti megoszlása

A legtöbb válaszadó 38,9\%-a Hajdú-Bihar megyéből való, 33,8\%-a él SzabolcsSzatmár-Bereg megyében és 27,3\%-a Jász-Nagykun Szolnok megyében lakik (3. ábra).

A felmért tanulók lakóhelye megye szerinti megoszlásban

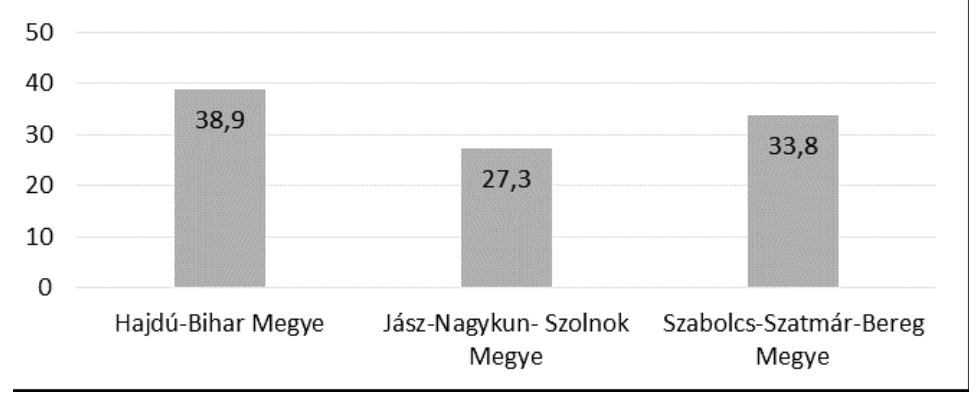

3. ábra: A válaszadók lakóhelye megye szerinti megoszlásban

Forrás: a szerzők, 2018 


\section{A tanulók attitüdje}

A sport megítélése pozitív a fiatalok körében, 78,4\%-a ( $\mathrm{n}=222)$ szeret sportolni. A válaszadó fiú tagjai nagyobb arányban szeretik a sportolást $(88,7 \%, \mathrm{n}=134)$, mint a lányok $(66,7 \%, n=88)$. Statisztikailag erős szignifikáns eltérést mutat a nemek között $\mathrm{Ch}^{2}$ négyzet próba: $20,298 \mathrm{Df}=1, \mathrm{P}=0,000$. A sportolási igények felmérésénél is hasonló eredményeket mutat, szignifikáns ( $\mathrm{Ch}^{2}$ négyzet próba: 8,813 , Df $=1, \mathrm{P}=$ $0,003)$ eltérés tapasztalható a nemek tekintetében, a fiúk 90,7\%-uk (n=137) igényli a sportolást, míg a lányoknál 78\%-uk $(\mathrm{n}=103)$. A kutatás során megvizsgáltuk azt is, hogy a tanulók képesnek érzik-e magukat arra, hogy sportoljanak, ennél a kérdésnél hasonlóan alakultak az eredmények, mint a sportolási igénynél összeségében az igen válaszok voltak többségben, valamint ennél a kérdésnél is kimutatható a nemek közötti szignifikáns különbség (Ch2 négyzet próba: 9,273 Df =1, P=0,002).

\section{Elégedettségi vizsgálat: külsö tulajdonságokról való vélemény}

Az elégedettségi vizsgálatot Likert-skálával végeztük, ahol az 1-es érték szerint egyáltalán nem tartották elégedettnek a külsőjüket, a 2-es jelentette, hogy az elégedettség kismértékü, a hármas azt jelentette, hogy közepesen van megelégedve, a négyes, hogy elégedett és az 5-ös értéke szerint teljes mértékben elégedettek a vizsgált elemekkel. Az erre vonatkozó eredményeket az 5. ábra szemlélteti. A kutatásból kiderült, hogy a megkérdezettek teljes mértékben 38,3\%-ban elégedettek a külsőjükkel. Tehát általánosságban a válaszadók Likkert-skálán az 5-ös értékéket határozták meg, vagyis mind a két nem teljes mértékben elégedett a külsöjével, a nemek között nincs szignifikáns eltérés.

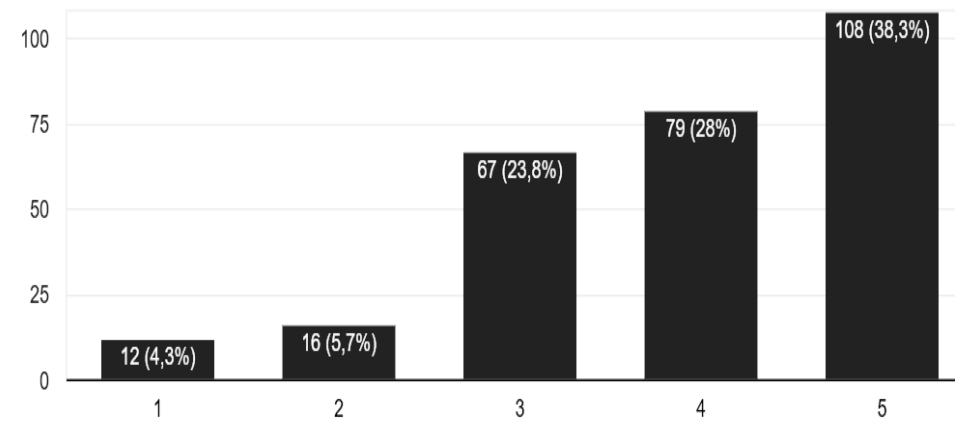

4. ábra: A válaszadók külső tulajdonságiakról alkotott véleményük

Forrás: a szerzök, 2018 


\section{A sportolási motivációk}

A sportolási motivációkról elmondható, hogy a nemek tekintetében hasonlóan alakultak. Mind a fiúk, mind a lányok válaszaiban a legjellemzőbb motivációs tényezők az egészség (23\%), a külső jegyek (19,1\%), a kikapcsolódás, szórakozás $(18,7 \%)$, valamint nagy súlya van az eredmények alapján a barátok, ismerősök (15,6\%) ösztönzésének. Legkevésbé befolyásoló hatású tényező az önbizalma erősítéséért (2,5\%) ösztönző ereje. Hasonló eredményről számol be nemzetközi kutatás, a sportban a szórakozás, örömforrás mellett fontos tényező a vonzóbb külső megjelenés és a testsúly kontrollálása, a fizikai megjelenés vonzóbbá tétele, illetve a baráti találkozások (Sports and Physical Activity Report 2014).

\begin{tabular}{|l|r|r|}
\hline \multicolumn{1}{|c|}{ A sportolás motivációi } & \multicolumn{1}{c|}{$\%$} & \multicolumn{1}{c|}{ Fö } \\
\hline A verseny kedvéért & 3,9 & 11 \\
\hline Önbizalmam erösitése érdekében & 2,5 & 7 \\
\hline Hogy ne legyek túlsúlyos & 5,7 & 16 \\
\hline Fittségem fejlesztése miatt & 8,3 & 24 \\
\hline Fizikai teljesítőképességem növelése érdekében & 3,2 & 9 \\
\hline Hogy új ismerősöket szerezzek & 9,2 & 26 \\
\hline Hogy a barátaimmal legyek & 6,4 & 18 \\
\hline Kikapcsolódás céljából & 10,6 & 30 \\
\hline Szórakozás céljából & 8,1 & 23 \\
\hline Hogy egészségesebb legyek & 23,0 & 65 \\
\hline Hogy jobban nézzek ki & 19,1 & 54 \\
\hline Összesen & 100,0 & 283 \\
\hline
\end{tabular}

1. táblázat: A válaszadók sportolási motivációi

Forrás: a szerzök, 2018

A sportolási motivációk feltérképezése mellet arra is kitért a kutatás, hogy mennyire értenek egyet azzal az állítással, hogy sportosok, valamint képesek versenyszerűen sportolni. A fiúk 56,3\%-a egyetértett az állítással, hogy „sportosok” a lányok viszont többségében a „semleges” választ adták 37,2\%-uk. Nemek tekintetében szignifikáns különbség figyelhető meg a fiúk sportosabbnak vélik magukat, mint a lányok (Ch2 négyzet próba: $16,236 \mathrm{Df}=2, \mathrm{P}=0,000)$. Az eredmények azt mutatják, hogy a fiú többsége egyetért azzal az állítással, hogy „képes versenyszerüen sportolni” 49,7\%-a, a lányok 34,8\%-a nem gondolja, hogy képes versenyszerün sportolni. Szignifikáns eltérést mutat a nemek között $\mathrm{Ch}^{2}$ négyzet próba: $12,533 \mathrm{Df}=2, \mathrm{P}=0,002$. 


\begin{tabular}{|c|c|c|c|}
\hline \multirow{2}{*}{$\begin{array}{l}\text { „Azt gondolom magamról, } \\
\text { hogy sportos vagyok” }\end{array}$} & \multicolumn{2}{|c|}{ Nemek } & Összesen \\
\hline & Fiú \% (Fö) & Lány \%(Fő) & $\%\left(\mathrm{Fo}^{\prime \prime}\right)$ \\
\hline Egyetértek & $56,3(85)$ & $34,8(46)$ & $46,3(131)$ \\
\hline Nem értek egyet & $12,6(19)$ & $28,0(37)$ & $19,8(56)$ \\
\hline Semleges & $31,1(47)$ & $37,2(49)$ & $33,9(96)$ \\
\hline Összesen & $100,0(151)$ & $100,0(132)$ & $100,0(283)$ \\
\hline Chi-négyzet próba & \multicolumn{3}{|c|}{$\operatorname{chi}^{2}=16,236 \mathrm{Df}=2, \mathrm{P}=0,000$} \\
\hline $\begin{array}{l}\text { „Azt gondolom magamról, } \\
\text { hogy képes vagyok } \\
\text { versenyszerüen sportolni” }\end{array}$ & Fiú & Lány & Összesen \\
\hline Egyetértek & $49,7(75)$ & $34,1(46)$ & $42,7(121)$ \\
\hline Nem értek egyet & $16,6(25)$ & $34,8(45)$ & $42,8(70)$ \\
\hline Semleges & $33,7(51)$ & $31,1(41)$ & $32,5(92)$ \\
\hline Összesen & $100,0(151)$ & $100,0(132)$ & $100,0(283)$ \\
\hline Chi-négyzet próba & \multicolumn{3}{|c|}{$\mathrm{chi}^{2}=12,533 \mathrm{Df}=2, \mathrm{P}=0,002$} \\
\hline
\end{tabular}

2. táblázat: A válaszadók véleményei

Forrás: a szerzök, 2018

\section{A sporttól való távolmaradás okai}

A részvétel ellen ható tényezők, vélemények szerint a sportolás ellen szól, hogy „nem ismeri a lehetőségeket” (29,9\%) és 16,4\%-uk ne kap segítséget az odajutásban. Nemzetközi kutatások is alátámasztják, hogy a fogyatékossággal élő személyek sportolása gyakran korlátokba ütköznek (EFDS 2013). A hátrányai közé tartozik továbbá, hogy „anyagi okai vannak” (14,2\%), illetve 12,7\%-a nem hiszi el magáról, hogy képes lenne erre. A megkérdezettek közül több mint 10\%-uk nem talál motivációt, nincs kedve sportolni. A „cikinek érzem” választ csak néhányan jelölték 5,2\%-uk. A nemek között ebben a tekintetben nincs különbség, az összes konkrét indokot hasonló mértékben említették a fiúk és a lányok is. 


\begin{tabular}{|c|c|c|}
\hline $\begin{array}{c}\text { Vélemények a fogyatékossággal élő tanulók a nem } \\
\text { sportolási motivációiról és okaikról }\end{array}$ & $\%$ & Fő \\
\hline Egészségi állapotom nem engedi & 9 & 25 \\
\hline Anyagi okai vannak & 14,2 & 40 \\
\hline Nem érdekel & 12,6 & 35 \\
\hline Nem vagyok képes rá & 12,7 & 36 \\
\hline Odajutásban nincs lehetőségem & 16,4 & 47 \\
\hline Nem ismerem a lehetőségeket & 29,9 & 85 \\
\hline Cikinek érzem & 5,2 & 15 \\
\hline Összesen & 100,0 & 283 \\
\hline
\end{tabular}

3. táblázat: A válaszadók véleményei a sporttól való távolmaradásról

Forrás: a szerzök, 2018

\section{Következtetések, javaslatok}

A fogyatékossággal élő fiatalok között markáns igény fogalmazódik meg a sportolás iránt. A fiúk sportolási igénye (90,7\%) szignifikánsan nagyobb a lányokétól (78\%). A sportolási motivációban az egészség, a külső megjelenés, a szórakozás-kikapcsolódás és a baráti társaság dominál, hasonlóak az épek körében végzett kutatások eredményeihez. A sporttól való távolmaradás okaiból kiemelkedik a „nem ismerem a lehetőségeket” és a nehéz az „odajutás” válaszok kapták a leggyakoribb említést. A fiúk sportosabbnak ítélik meg magukat és többen ítélik, meg magukat úgy, hogy képesek is sportolni a lányokhoz képest $(\mathrm{p}<0,05)$.

Mivel a fogyatékossággal élö gyerekek igen magas aránya jelezte, hogy igénye van sportolni, de az információ hiánya vagy az odajutás ezt nehezíti. Így az iskolai sportkínálat biztosítása lehet a megoldás erre a problémára. A motivációvizsgálatok tapasztalatai segítenek bennünket abban, hogy mik legyenek azok a hívószavak, melyeket a sportkínálat promóciójába beépítsünk.

A publikáció elkészitését az EFOP-3.6.2-16-2017-00003 számú projekt támogatta. A projekt az Európai Unió támogatásával, az Európai Szociális Alap társfinanszirozásával valósult meg. 


\section{Hivatkozott Források}

[1.] Bácsné B. É. - Balogh R. - Bács Z. - Fenyvesi V. - Dajnoki K. (2018): Sportszolgáltatások Keresleti, Kinálati Oldalának Elemzési Lehetöségei. Studia Mundi - Economica 5: 3 (2018) pp. 19-33. Paper: 10.18531/Studia. Mundi.2018.05.03.19-33, 15 p. (2018).

[2.] Balázs-Földi E. (2017): Fogyatékos és megváltozott munkaképességü személyekkel kapcsolatos ismeretek összehasonlitó elemzése Hajdú-Bihar megye három járásában. Taylor: Gazdálkodás- és Szervezéstudományi Folyóirat: A Virtuális Intézet Közép-Európa Kutatására Közleményei 29-30:(3-4) pp. 2634.

[3.] Block, M. E. - Taliaferro, A. - Moran, T. (2013): Physical Activity and Youth with Disabilities. Barriers and Supports. Prevention Researcher 20: 18.

[4.] Bocsi V. - Rákó E. (2015): A sajátos nevelési igényü gyermekek integrált nevelése, mint a tanári pálya egy lehetséges kimenete pp. 205-216., 12 p. In: Szilágyi, B., Mező, K., Mező, F. (szerk.) Az együttnevelés útjai. Debrecen, Magyarország: Debreceni Egyetemi Kiadó, (2015) p. 263.

[5.] Bota A. - Teodorescu S. - Serbanoiu S. (2014): Unified Sports - a Social Inclusion Factor in School Communities for Young People with Intellectual Disabilities. 3rd International Congress on Physical Education, Sport and Kinetotherapy (Icpesk 2013) 117: 21-26.

[6.] EFDS (2013): Disabled People's Lifestyle Survey. English Federation of Disability Sport. Letöltés időpontja:2018.12.01.file://C:/Users/noral/ Downloads/EFDS_Disabled_People_s_Lifestyle_Survey_Report_ Sept_2013.pdf.

[7.] Hidvégi P. - Bíró M. - Lenténé P.A. - Pucsok J. M. - Tatár A. (2018): Fogyatékkal élők turizmusának lehetöségei az észak-alföldi régióban. 158164.p. In: Válogatott tanulmányok a sporttudományok köréből. 1. sz. 186.p. Debreceni Egyetem Sporttudományi Koordinációs Intézet, Debrecen.

[8.] Laczkó T. - Rétsági E. (2015): A sport társadalmi aspektusai. PTE, Pécs.

[9.] Mező K. - Mező F. (2017): Fogyatékossággal élö gyermek a családban. In: Vargáné, Nagy A. (szerk.) Családi nevelés (Vol.2, pp. 79-89). Debrecen, Magyarország. Didakt Kft.

[10.] Sáringerné Sz. Zs. (2014): A fogyatékkal élök sportolási lehetöségei. In: Dóczi, T. - Gál, A. - Sáringerné Sz. Zs. (szerk.). Társadalmi befogadás a sportban és a sport által (szociális inklúzió). In: A fizikai aktivitás és a sport magyarországi dimenzióinak feltárása. 74-141. MST-MSTT, Budapest. 
[11.] Sports and Physical Activity Report (2014): Special Eurobarometer 412. European Commission.

[12.] Székely L. (szerk.) (2013): Magyar Ifjúság 2012. Kutatópont.

[13.] Székely L. - Szabó A. (szerk.) (2017) Magyar Ifjúság Kutatás 2016. Társadalomkutató Kft.

[14.] Tatár A. - Lenténé P.A. - Bíró M. - Pucsok J. M. - Hidvégi P. (2018.): Észak-alföldi régió szolgáltatóinak hozzáférés biztosítása a speciális igénnyel élők számára. 150-157.p. In: Válogatott tanulmányok a sporttudományok köréből. 1. sz. 186.p. Debreceni Egyetem Sporttudományi Koordinációs Intézet, Debrecen.

[15.] Tóthné K. K. - Gombás J. (2016): A sport hatása a fogyatékossággalélo"személyek életminőségére. In: Hamar P. (szerk.): A mozgás, mint személyiségfejlesztő tényező. Eötvös József Könyvkiadó, Budapest pp.115-141.

[16.] WHO (2018): Physical activity factsheets for the 28 european union member states of the who european region. Letöltés időpontja: 2019.01.07. 01. file://C:/Users/user/Downloads/physical-activity-factsheets-2018eu28who_ennew\%20(1).pdf. 


\section{Szerzők:}

\section{Laoues-Czimbalmos Nóra, PhD}

Tanársegéd

Debreceni Egyetem

Gyermeknevelési és Gyógypedagógiai Kar

laoues.nora@ped.unideb.hu

\section{Dr. Bácsné Dr. habil Bába Éva}

Egyetemi docens, Tanszékvezető

Debreceni Egyetem

Gazdaságtudományi Kar, Sportgazdasági és -Menedzsment Tanszék

bacsne.baba.eva@econ.unideb.hu

\section{Szerdahelyi Zoltán}

Tanársegéd

Debreceni Egyetem

Gyermeknevelési és Gyógypedagógiai Kar

szerdahelyi.zoltan@ped.unideb.hu

\section{Dr. habil Müller Anetta}

Egyetemi docens

Debreceni Egyetem

Gazdaságtudományi Kar, Sportgazdasági és -Menedzsment Tanszék muller.anetta@econ.unideb.hu 